\title{
Ecopoetics and Aranya in the Graphic Novel Aranyaka: Book of the Forest
}

\author{
Shivani Sharma ${ }^{1} \&$ Arnapurna Rath ${ }^{2}$ \\ ${ }^{1}$ Research Scholar Humanities and Social Sciences, Indian Institute of Technology Gandhinagar, \\ Gandhinagar, Gujarat, India. Email: shivani.sharma@iitgn.ac.in \\ ${ }^{2}$ Assistant Professor Humanities and Social Sciences, Indian Institute of Technology \\ Gandhinagar, Gandhinagar, Gujarat, India. Email: arnapurna@iitgn.ac.in
}

\begin{abstract}
The crucial nexus between ecology, forest, forest dwellers, and their position in the ancient genres of literature and art is a significant area of aesthetic contemplation. Ancient Indian literary traditions have remarkable eco-sensitivity and display their own style of ecopoetics (signified by genres such as the Aranyakas). This study presents a critical analysis of the graphic novel Aranyaka: Book of the Forest (2019) -- an artistic retelling based on Puranic tales, the Upanishads, and a special literary genre called the Aranyakas (because these texts were composed in the forests). This graphic novel is the culmination of an artistic collaboration between the graphic artist Amruta Patil and the Indian mythologist Devdutt Pattanaik. The novel has complex visual metaphors that are based on the intimate stories of the well-known Indian sage Yājñavalkya, his wives Katyayani and Maitreyi, and a dialogue with his disciple Gargi. The graphic novel presents fragments of stories based on the concealed wisdom of the Brihadaranyaka Upanishad. The novel is a "play" on the perceived dualisms of Nature and Culture, Savage and Civilised. The text is dialogic in its structure. There is an interplay of visual art with verbal metaphors from ancient Indian tales.
\end{abstract}

Keywords: Graphic Novel, Upanishads, Metaphor, Visual Media, Mythology, Indian Folk Tales, Philosophical Aesthetics.

The graphic novel Aranyaka: Book of the Forest (2019) is an experimental narrative based on an artistic collaboration between the graphic artist Amruta Patil (1979-present) and the Indian mythologist Devdutt Pattanaik (1970-present), celebrating the significance of Nature in Upanishadic thoughts. ${ }^{1}$ The text is a visual-verbal bonanza of the complex wisdom concealed in the Brihadaranyaka Upanishad (9 $9^{\text {th }}$ to $6^{\text {th }} \mathrm{BCE}$ ), which embodies a dialogue between the saint Yājñavalkya ( $8^{\text {th }}$ BCE and $7^{\text {th }}$ BCE) and Gargi ( $7^{\text {th }}$ BCE) regarding knowledge of the self. ${ }^{2}$ Aranyaka is the third text in a series of two previous graphic novels of Patil based on Indian folk and mythological stories; Adi Parva: Churning of the Ocean (2012) and Sauptik: Blood and Flowers (2016). ${ }^{3}$ The novel displays a strong ecological consciousness and nature sensitivity. The novel has complex visual metaphors that are based on the intimate stories of the well-known Indian sage Yãjñavalkya, his wives Katyayani and Maitreyi, and a dialogue with his disciple Gargi. ${ }^{4}$ Maitreyi is the source of great philosophical treatises. However, the 
graphic narrative has privileged Katyanani's position in Yājñavalkya's story. ${ }^{5}$

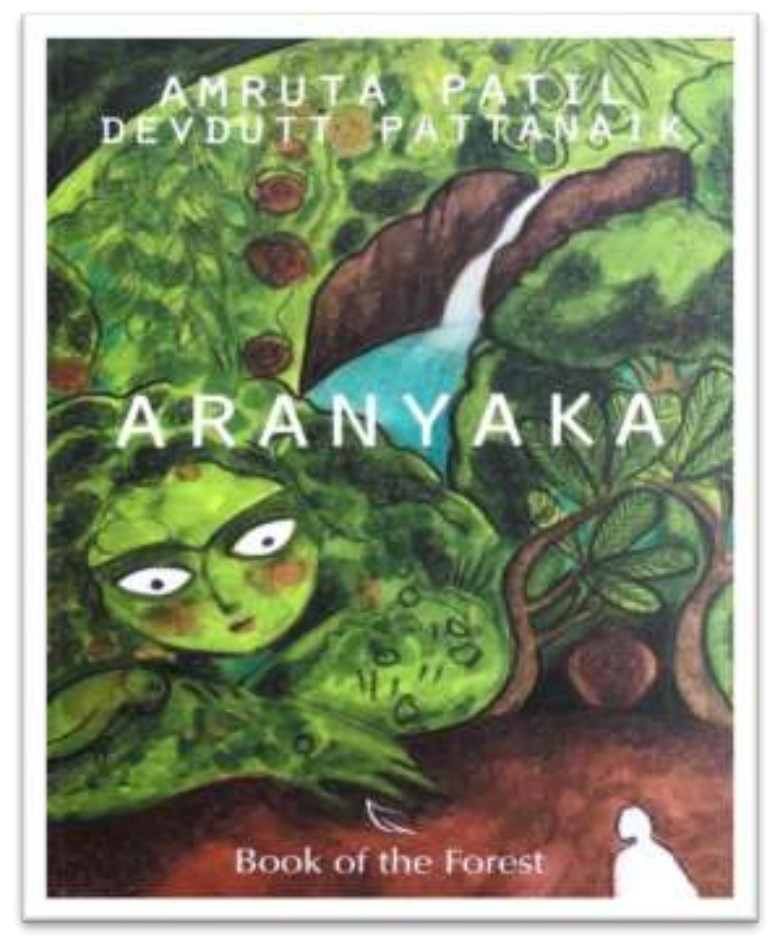

Illustration 1: The cover-page of the graphic novel Aranyaka (Patil \& Pattanaik, 2019, p.86)

Yājñavalkya's thoughts are contained in the great discourse or "lesson" of Satapatha Brahmana which is the initial text that leads to the dense philosophical commentary of the Brihadaranyaka Upanishad (Müller,1884,p.130). ${ }^{6}$ The linking knot between Satapatha Brahmana and the Upanishads is Brahmodaya -- a dialogue between King Janaka of Videha and Yājñavalkya. Logically, this intimate story of the discussion between Yājñavalkya, Maitreyi and Katyayani form towards conclusion of the Brihadaranyaka Upanishad (Calasso,2010,p.68). These are rich documents of classical Indian literature, which are hardly accessible.

The novel is a creative retelling of Puranic tales, based on the life of the famous sage Yājñavalkya. ${ }^{7}$ Vettam Mani (1921-1987) in the Puranic Encyclopaedia (1964) introduces the sage Yājñavalkya, Maitreyi and Katyayani. Mani states that Yãjñavalkya was, "an ancient sage who was a profound scholar. Purānas say that this sage spent the major part of his life at the court of King Janaka. He was also King Janaka's priest...In Mahābhārata, Anusasna Parva, Chapter 4, Verse 51, mentions that Yãjñavalkya was a "Brahmavadi son" of Visvamitra" (Mani,1964,p.891). There are two streams of disciple-hood in the ancient Indian philosophical systems -- Brahmavadi and Tattvavadi. Brahmavadi scholars discussed the immense power of the "Absolute Truth" hidden in the universe. The idea of "son" here refers to a close disciple. Yājñavalkya's first wife Maitreyi is mentioned as "the most learned and virtuous women in ancient India" (Mani,1964,p.469). She is one of the celebrated women philosophers in ancient Indian philosophy. ${ }^{8}$ His other wife, Katyayani is described as a quintessential householder who has to "undertake the burden of all material affairs" (Mani,1964,p.399). She remains as the mother of Yaajñavalkya's children and a marginalised voice in the brilliance of knowledge and philosophical ecosystem personified in the triumvirate of Yãjñavalkya, Gargi and Maitreyi. 
The title of the graphic novel Aranyaka refers to a forest. In a metaphorical sense, Aranyaka also refers to the dense "forest" of philosophical inquiry and denotes the problem of knowledge in its essence. The graphic novel (re)interprets the character of Katyayani for the thematic inspiration and (re)reads her in the contemporary context. It is a fictional reading of Katyayani, who had remained as a lesser-known individual in Yājñavalkya's extraordinary life. The graphic novel speaks of intersections of environmentalism and feminism through a reinterpretation of these ancient mythologies. The narrative opens alternative points of view of the oral tales. The forest in Aranyaka is a character by itself. It has its unique traits and has different meanings for its indwellers. Patil states that, "the forest here isn't romanticised-it is a place that is as unmaliciously violent as it is beautiful" (Patil \& Pattanaik,2019,p.162). The forest in Aranyaka is not simply mythologised in the lore. Each character in the graphic tale shares a unique bond with the forest that is divided in dualisms, such as love and hate, spiritualism and materialism, knowledge and ignorance.

In the Vedic literature, Aranyaka (700 BCE) as a text is a part of the commentaries on the Vedas (1500-1200 BCE) which constitutes, "not only the explanation of the sacrificial rites, but the relevant texts themselves and their mystic and allegorical, 'symbolical' and 'philosophical' significance" (Gonda,1975,p.423). The reference of Aranyaka appears in the Mahābhārata (1883) as the first section of Vana Parva (Ganguli,1883,p.1). In Vana Parva, Pandavas embark on their journey to the forest in order to spend twelve years during their exile. Aranya (forest) played a crucial role in the lives of the Pandavas in their journey through the forest of Kamyaka, the Trithas or the holy places to the forest of Dwaita in order to learn the art of spiritualism (Ganguli,1883,p.157). In the graphic narrative, Katyayani and Yãjñavalkya developed an intimate connection with the forest like the Pandavas in Vana Parva. The life of Katyayani and Yãjñavalkya is a parable that deals with dense philosophical issues. Patil explains the reasons for selecting Katyayani as the storyteller of the narrative. She says,

"I suggested creating a parable- a love story maybe or a story about rivalries or foodsomething disarmingly simple that you could finish reading without even realising you had just emerged from an immersive swim in Vedic ideas" (Patil \& Pattanaik,2019,p.166).

Instead of Yãjñavalkya, Katyayani becomes the centre of Patil and Pattanaik's Aranyaka. This does seem like a conscious choice. The authors provide a new structure to the tale by displacing Yãjñavalkya and Maitreyi as the central characters. The graphic novel presents a macro-cosmic world of the Upanishadic thoughts and traditions based on a journey of selfdiscovery of Katyayani.

The graphic narrative is supplemented with a dialogue between the two authors in order to convey the design of their version of the lore. According to Pattanaik, "Vedic thought" is defined as, "to be cultured and civilised: the journey from hunger and fear, through domestication, towards empathy" (Patil \& Pattanaik,2019,p.161). The undercurrent motifs in the graphic narrative such as hunger and kitchen play a significant role in the tale. The journey of Aranyaka is the journey of Katyayani composed through her various roles, beginning from the search to satiate her hunger in the forest, to the domestic life with Yaajñavalkya, and learning the art of self-discovery.

Patil has extensively used water-coloured pallets and drawing pencils to show the intensity of the shades of the forest in contrast to the civilised world (Patil \& Pattanaik,2019,p.86). The frame in the cover-page of the graphic narrative (see illustration 1) represents Katyayani 
glaring at the silhouette of the civilised human being (Patil \& Pattanaik,2019,p.86). She has been shown as an integral part of Nature vis-à-vis the cultural evolution symbolised by Yājñavalkya and his disciples. The forest is represented as an indivisible part of Katyayani's life and her journey to the civilised world. The graphic narrative unravels through the layered frames into the panels as follows: (a) forest, (b) others, (c) field, (d) grove, (e) rivals, ( $f$ ) classroom, (g) exchange, and (h) ladle. The section titled as the "forest" familiarised Katyayani to the concepts of nature. Katyayani is introduced in the novel as, "I am Katyayani the Large. The warp of my story has always been hunger" (Patil \& Pattanaik,2019,p.2). The forest has played a pivotal role in this transition of Katyayani, who grew into a "predator, prey, ally, rival, mate" (Patil \& Pattanaik,2019,p.22). The forest in Aranyaka has the capacity to unfold itself to those who strive to learn from life. It is a remarkable symbol of the survival of the fittest denoting a struggle between the savage and the civilised. It is not bound by any geographical markers and territorial limitations.

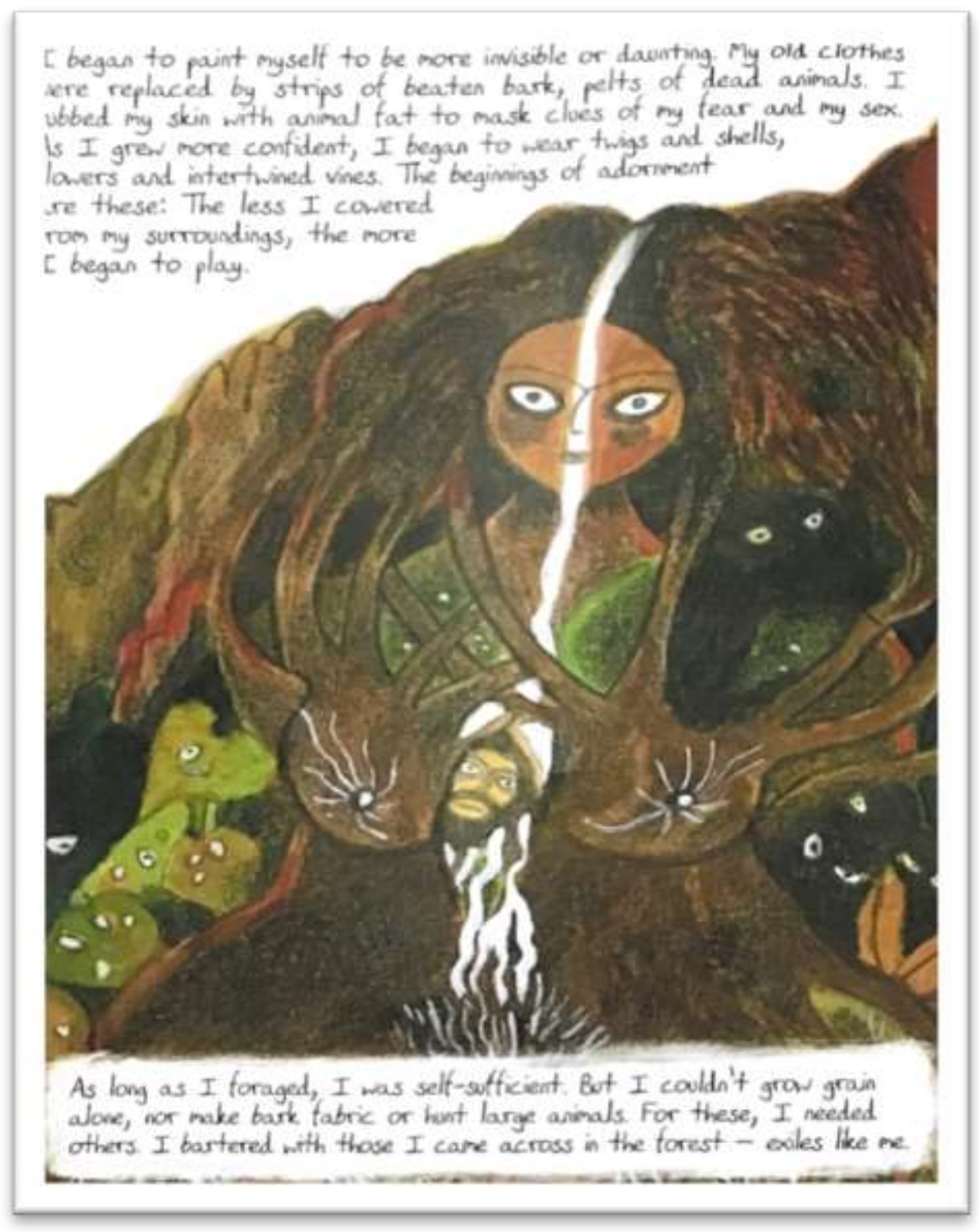

Illustration 2: The Encounter between Katyayani and Yājñavalkya in the forest (Patil \& Pattanaik,2019,p. 28) 
The subsequent sections of Aranyaka such as "others", "field" and "grove" contrive the journey of Katyayani from the forest to civilisation, especially her role in Yãjñavalkya's life. There is a clear distinction between the world of Yãjñavalkya and her own. She says, "the forest as $Y$ (Yãjñavalkya) knew it was so different from the forest I knew" (Patil \& Pattanaik,2019, p.42). Katyayani was born in the forest, and Yãjñavalkya had moved to the forest in the quest of knowledge. Katyayani and Yãjñavalkya function as the two knots in the braid of the circle of life in Aranyaka that they have to travel together.

Aranyaka provides an opportunity for the readers to delve into the forest and domestic life of Katyayani and Yãjñavalkya. The authors have ascribed the term "membrane" to distinguish between the distinctive parts of the graphic novel (Patil \& Pattanaik,2019,p.56). This term signifies a palpable, fleshly separation that happens in the mind of human beings demarcating the forest from the city or the civilised landscape. The "membrane" percolates the mind of Katyayani (Patil \& Pattanaik,2019,p.56). She performs her role in domestic life and eventually a distance is built between Katyayani and Yãjñavalkya after the construction of the home as a separate dwelling from the forest spaces (Patil \& Pattanaik,2019,p.56). The forest has remained as a part of their "membrane" and a metaphor for Katyayani and Yājñavalkya. The forest provides a semblance of Katyayani's transformation from being a wild survivor to a domesticated wife of a great sage, living within confined boundaries.

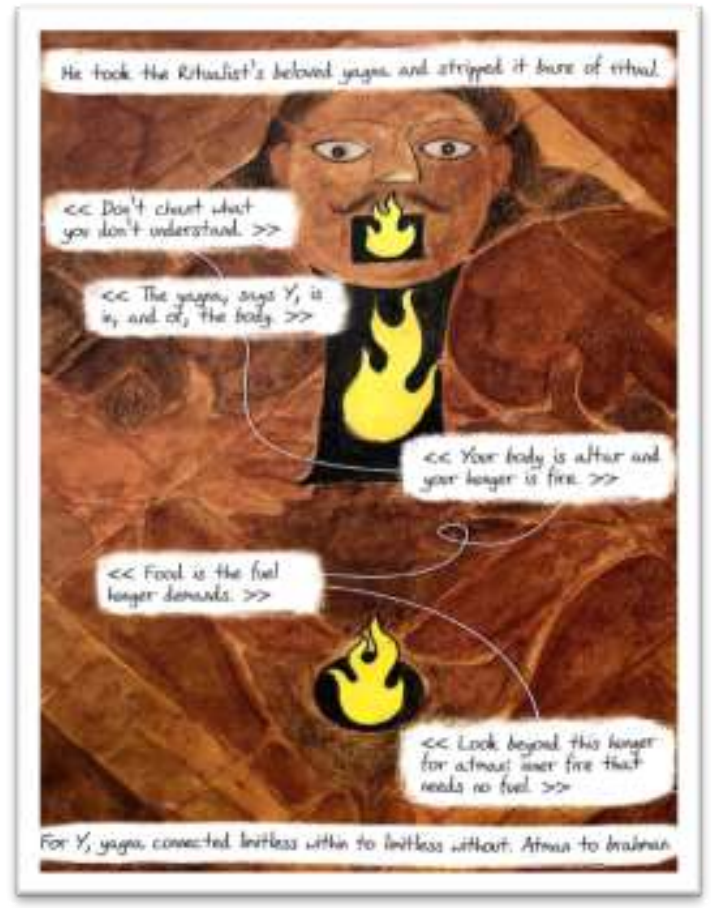

(a)

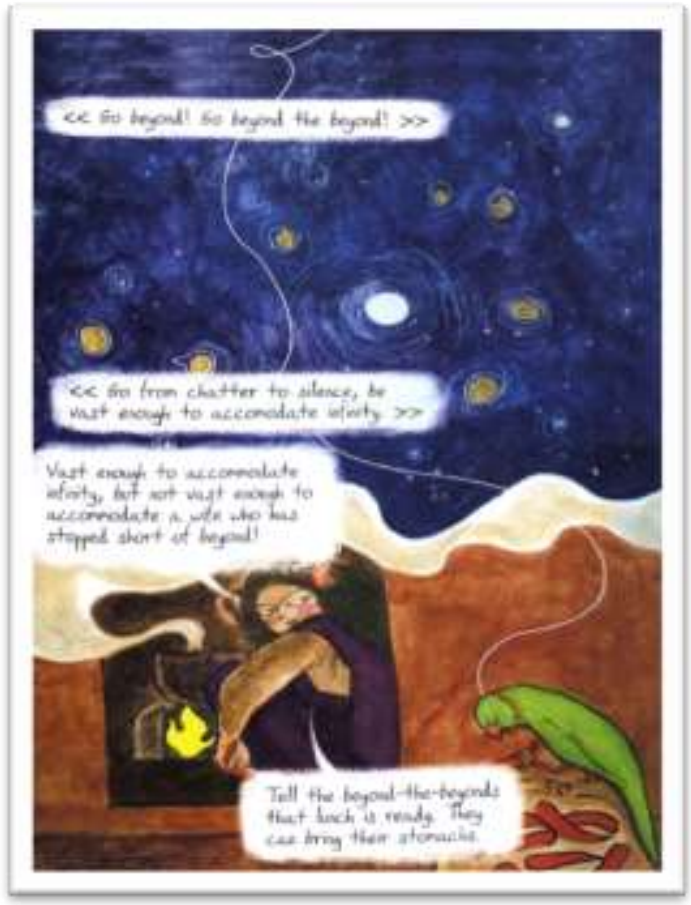

(b)

Illustration 3: (a) The Ritual of "Yagna" performed by Yãjñavalkya,

and (b) the Kitchen of Katyayani (Patil \& Pattanaik,2019,pp.126-131)

Further, the segments such as "rivals", "classroom" and "exchange" artfully display the complexities and the distance developed in the lives of Katyayani and Yājñavalkya. Yājñavalkya builds his classroom to practice the art of seeking knowledge (Patil \& Pattanaik,2019,p.126). On the other hand, Katyayani is performing the household chores without help and appreciation from Yãjñavalkya (Patil \& Pattanaik,2019,p.131). The tale of Katyayani is a narrative of a neglected wife. In this context, the panels in illustration 3 represent two 
distinctive frames juxtaposed to depict fire as a twofold metaphor: (a) the art of "yagna" (the holy-fire) performed by Yãjñavalkya in his classroom as part of the methodological practice of early Vedic knowledge, and (b) the use of fire in Katyayani's kitchen to perform daily household chores (Patil\& Pattanaik,2019,pp.126-131). Fire becomes the symbolic expression of early civilisations, having the twin purpose of satiating the basic hunger for knowledge and for food. The two frames bring a unique juxtaposition and a distinctive aspect to the approach of Yãjñavalkya and Katyayani. Fire appears as a mythological figure with an openmouth in Yãjñavalkya's classroom while performing the ritual of "yagna" (see illustration 3 (a)). In Katyayani's life, fire becomes amiable through the use in cooking food. Patil and Pattanaik have used the term "sutra" in illustration 3 to stitch the dialogues of the tale into a thread (Patil \& Pattanaik,2019,p.168). The text is dialogic in its structure. Similarly, each frame in the graphic novel is engraved with "Vedic" thoughts and expressions. ${ }^{9}$

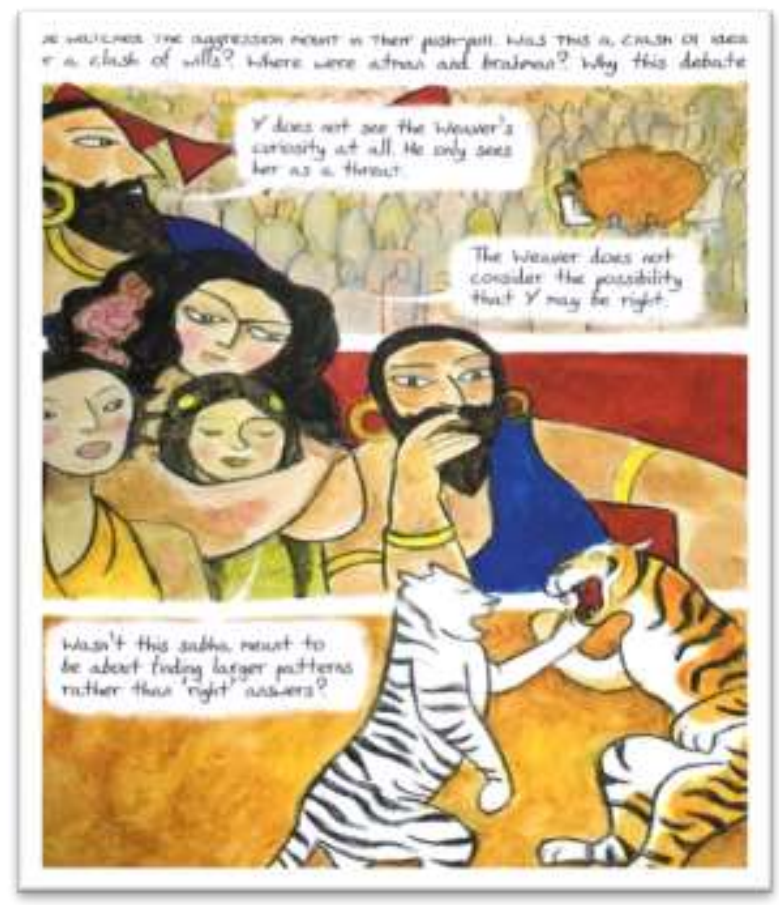

Illustration 4: The debate between Yājñavalkya and the Weaver (Patil \& Pattanaik,2019, p.145)

The universe of Aranyaka brings forth a reference to Puranic stories and Vedic thoughts within the framework of a graphic novel. The dialogue between Yãjñavalkya and Gargi has been depicted through metaphoric language signified by the "weaver" and with references to animals such as a whale and an argument between two tigers (Patil \& Pattanaik,2019, pp.144-145). Gargi was a weaver in her profession, and she drew philosophical inspiration in her discussion with Yãjñavalkya by providing references to her trade, for instance, the relationship between the weft and the weaver. The visual rendering of these stories has distinctive relations with legends associated with Yãjñavalkya and Gargi. Roberto Calasso in Ardor (2010) discusses the response of Yaajñavalkya to Gargi regarding the notion of the devourer and devoured (Calasso,2010, p.67). Patil and Pattanaik have artfully depicted this story in the visual metaphor of a whale inside a whale (Patil \& Pattanaik,2019, p.144). In the philosophical argument between Yãjñavalkya and Gargi with reference to Brihadaranyaka Upanishad, this universal chain of devourer and devoured is signified by the web of Time and Space. Yãjñavalkya says, 
"the weft of that which is, of that space with which even ungraspable time is woven, is made of this...and that weft is indestructible" (Calasso,2010,p.68). In the graphic narrative, the whale signifies the indestructible nature of Time and Space (Patil \& Pattanaik,2019, p.144). These are dense philosophical thoughts associated with ancient Indian literature signifying Tarka Sastra (argumentation) and Vaisheshika (logic).

The panel in illustration 4 represents the metaphysical debate between Yãjñavalkya and the weaver (Gargi) on the art of seeking knowledge. The argument takes place in king Janaka's assembly hall. Gargi, a disciple of Yaajñavalkya enquires on the philosophical notion of the nature of the universe and discusses the concept of Brahman (Müller,1884,p.131). The metaphysical argument between the two is (re)visualised by the authors of the graphic tale in a frame. The panel depicts the argument through the visual metaphor of the two tigers (Yãjñavalkya and the weaver) debating in the midst of the assembly hall (see illustration 4). The selection of animal metaphor suggests a conscious choice of the artists to weave the shades from Aranya (the forest) into the world of these knowledge seekers. A reader has to dwell with each thread (sutra) woven into the narrative to understand the consequences of the metaphysical debate and the layered structure of the world of Aranyaka.

Thus, Patil and Pattanaik recreate the legend of Yãjñavalkya at the conceptual level and invest their visual imagination in creatively experimenting with the tale. Aranyaka can inspire readers and direct them to read about Yājñavalkya's extraordinary life as enumerated in Purānas such as Agni Purāna and the Mahābhārata. In the Mahābhārata, Yājñavalkya is mentioned in Santi Parva as an associated character who has a functional role in the epic relegated to a minor position in the tale. However, Patil and Pattanaik recognise the significance of Yãjñavalkya as a standalone character through their readings of various Purānas and folklores. Patil and Pattanaik's retelling in the form of the graphic narrative takes poetic license to a large extent and they have creatively (re)used materials from Puranic tales to construct a "play" of their version of the narrative. An unsuspecting reader might fall into the artful trap of a contemporary narration that may or may not have a direct relationship with the biographical tales of Yãjñavalkya. As a sage, Yãjñavalkya made it a point to have knowledge reach beyond the demarcation of gender and his disciples such as Gargi and Maitreyi (who was also his wife) were extraordinary scholars. Katyayani made a conscious choice to take up the role of the manager of his household and domestic chores (Calasso,2010,p.78). The novel can be considered as a "play" on the information regarding the lives of these characters. However, the information provided in the artistic narration, cannot be taken as complete knowledge. The novel may be read as an early step that lead readers to seek deeper information and to learn more about the life and work of Yãjñavalkya, Maitreyi, Gargi and Katyayani. It has succeeded to a great extent in arousing an interest in the lives of the great sages. The novel is a puzzle in itself that demands advanced reading and critical insight regarding ancient Indian literature and philosophical systems. Readers who are interested to look deeper into the literary gems of the sub-continent may be interested to access the source texts for further reading.

The novel depicts the constructed binaries of gender roles between man and woman, between man and animal, and between forest and society by situating the central characters in a forestscape. The reading of Aranyaka can serve as an experience and help to read/refresh our knowledge of Puranic thoughts. ${ }^{10}$ Through the art of reading of Puranic tales as open-ended, dialogic narratives, the reader can enter aesthetically and philosophically into the well-knitted panels of Aranyaka to find his/her resonance with the mythic lore. In spite of the advanced position of human beings as sages and seers of Aranyaka, they are still an integral part of the 
larger ecological dimension and are a tiny component of the ecopoetics of the creation. ${ }^{11}$ Yãjñavalkya, his wives and even his celebrated disciples like Gargi are human species -merely another species in the larger ecopoetics of the universe.

\section{Notes}

${ }^{1}$ Monier Williams in A Sanskrit-English Dictionary (1899) defines "aranya" as a land which is "neither cultivated nor grazed; a wilderness, desert, forest" (Williams,1899,p.80). Aranyaka is the text composed with Brahmanas which contains a philosophical insight and learnings from the practice of performing rituals. Gabe Hiemstra discusses the significance of Aranyaka in "Buddhism, Pali, Hinduism, Sanskrit, history of ancient India, and Marathi" (Hiemstra, n.d.). In Sanskrit, Aranyaka is associated with something which is "relating to or produced in a forest, wild, forest-born" (Hiemstra, n.d).

${ }^{2}$ Brihadaranyaka Upanishad from the Upanishad was translated by the German Indologist Max Müller (1823-1900) in 1884. The Upanishad discusses the philosophical discourse between the sage Yājñavalkya and Gargi Vachaknavi (Müller,1884,p.130).

${ }^{3}$ Varsha Jha (Singh) and Mini Chandran provides a critical reading on Amruta Patil's graphic novel titled Adi Parva: Churning of the Ocean (2012) in their article "Reading a Retelling: Mahabharata in the Graphic Novel Form" (2017).

${ }^{4}$ The authors in Aranyaka have used the abbreviation of " $Y$ " for Yãjñavalkya as a casual fictionalised expression (Patil \& Pattanaik,2019,p.35).

${ }^{5}$ In the context of Yãjñavalkya's story, the reference of Katyayani in the graphic novelAranyaka should not be confused with one of the nine forms of the Hindu goddess Durga.

${ }^{6}$ Refer to Julius Eggeling's work Satapatha Brahmana (1882) for a more detailed understanding on Satapatha Brahmana.

${ }^{7}$ Refer to the work of K.R.Krishnaswami titled the Amazing Life of the Sage Supreme Yajnavalkya and his Towering Role in Brihadaaranyaka (2007) for a biographical discussion on Yājñavalkya's life.

8 Paul Deussen in his work the Philosophy of the Upanishads (1906) discusses in detail about the division of the genres of the ancient Indian literature.

${ }^{9}$ The authors of Aranyaka have provided an index of the Vedic concepts which "inspired every frame" of the graphic novel (Patil \& Pattanaik,2019,p.173).

${ }^{10}$ Kalki is considered to be as one of the incarnation of the Hindu God Vishnu which will appear in the cycle of Kali-yuga. M.N.Dutt in the work The Agni Puranam (1904) discusses Yãjñavalkya as the priest of Kalki (Dutt,1904,p.74).

11 Jonathan Bate describes ecopoetics in the work The Song of the Earth (2000) as "it asks in what respects a poem may be a making (Greek poiesis) of the dwelling place - the prefix eco- is derived from Greek oikos, 'the home or place of dwelling.' According to this definition, poetry will not necessarily be synonymous with verse: the poeming of the dwelling is not inherently dependent on metrical form. However, the rhythmic, syntactic and linguistic intensifications that are characteristic of versewriting frequently give a peculiar force to the poiesis. it could be that poiesis in the sense of versemaking is language's most direct path of return to the oikos, the place of dwelling, because metre itself - a quiet but persistent music, a recurring cycle, a heartbeat - is an answering to nature's own rhythms, an echoing of the song of the earth itself" (Bate,2000,p.76). 
9 | Ecopoetics and Aranya in the Graphic Novel Aranyaka: Book of the Forest

\section{References}

Patil, A., \& Pattanaik, D. (2019). Aranyaka: Book of the Forest. Westland Publications Private Limited.

Patil, A. (2012). Adi Parva: Churning of the Ocean. HarperCollins Publishers India.

Patil, A. (2016). Sauptik: Blood and Flowers. HarperCollins Publishers. Mani, V. (1964). The Puranic Encylopaedia. Motilal Banarsidas.

Ganguli, K.M.(1883). The Mahābhārata, Vana Parva. Munshiram Manoharlal Publishers.

Ganguli, K.M.(1883). The Mahābhārata, Santi Parva. Munshiram Manoharlal Publishers.

Müller, F. M trans. (1884). The Upanishads. Oxford, The Clarendon Press.

Gonda, V. (1975). A History of Indian Literature. Otto Harrassowitz Wiesbaen.

Krishnaswami, K.R.(2007). The Amazing life of the Sage Supreme Yājñavalkya and His Towering Role in Brihadaaranyaka. A and K Prakashana.

Hiemstra, G.(n.d). "Aranyaka, Āranyaka, Aranyaka: 13 definitions." Wisdom Library. Retrieved April 5, 2020, from https://www.wisdomlib.org/definition/aranyaka.

Jha (Singh), V., \& Chandran, M.(2017). "Reading a Retelling: Mahabharata in the Graphic Novel Form." Journal of Graphic Novels and Comics, vol.9, no.4, 373-390. https://www.tandfonline.com/doi/citedby/10.1080/21504857.2017.1355823.

Dutt, M.N.(1904). The Agni Puranam. Cosmo Publications.

Williams, M.(1899). A Sanskrit-English Dictionary. The Clarendon Press, Oxford. Deussen, P. (1906). The Philosophy of Upanishads. Dover Publications.

Calasso, R. (2010). Ardor. New York, Farrar, Straus and Giroux. Eggeling, J. (1882). Satapatha Brahmana. Shri Jainendra Press.

Bate, J. (2000). The Song of the Earth. Picador, London.

Shivani Sharma is a Research Scholar in the department of Humanities and Social Sciences at the Indian Institute of Technology Gandhinagar, Gujarat. Her research interests entail Epic studies, Semiotics, and New Media studies. In her doctoral research, she is developing an analysis of Epic narrative with a special focus on the Mahābhārata and media platforms. She can be reached at shivani.sharma@iitgn.ac.in

Arnapurna Rath is Assistant Professor in the department of Humanities and Social Sciences at the Indian Institute of Technology Gandhinagar, Gujarat. Her research interests are broadly in the fields of Comparative literature, South Asian narratives, and Digital Humanities. She can be reached at arnapurna@iitgn.ac.in 